\title{
Rapid identification of bovine mastitis pathogens by MALDI-TOF Mass Spectrometry ${ }^{1}$
}

\author{
Patrícia A.C. Braga² , Juliano L. Gonçalves ${ }^{3}$, Juliana R. Barreiro ${ }^{3}$, \\ Christina R. Ferreira ${ }^{2}$, Tiago Tomazi ${ }^{3}$, Marcos N. Eberlin ${ }^{2}$ and Marcos V. Santos ${ }^{3 *}$
}

\begin{abstract}
Braga P.A.C., Gonçalves J.L., Barreiro J.R., Ferreira C.R., Tomazi T., Eberlin M.N. \& Santos M.V. 2018. Rapid identification of bovine mastitis pathogens by MALDI-TOF Mass Spectrometry. Pesquisa Veterinária Brasileira 38(4):586-594. Departamento de Nutrição e Produção Animal, Faculdade de Medicina Veterinária e Zootecnia, Universidade de São Paulo, Av. Duque de Caxias Norte 225, Pirassununga, SP 13635-900, Brazil. E-mail: mveiga@usp.br

Matrix-assisted laser desorption/ionization time-of-flight mass spectrometry (MALDI-TOF MS) has been shown to be an alternative method for identification of bacteria via their protein profile spectra, being able to identify bacteria at the genus, species and even at subspecies level. With the aim of large-scale identification of pathogens causing mastitis by this platform, a total of 305 isolates of bacteria identified from cows with subclinical mastitis were analyzed by conventional microbiological culture (MC) as well as by MALDI-TOF MS coupled with Biotyper data processing. Approximately $89 \%$ of the identifications performed by MALDI-TOF MS were consistent with results obtained by MC. From the remaining isolates (11\%), 6.3\% of isolates were classified as misidentified (discordance for both genus and species level), and $4.7 \%$ showed identification agreement at the genus level but not at the species level, being classified as unidentified at species level. The disagreement results were mostly associated with identification of Streptococcus and Enterococcus species probably due to the narrow phenotypic similarity between these two genera. These disagreement results suggest that biochemical assays might be prone to identification errors and, MALDI-TOF MS therefore may be an alternative to overcome incorrect species-specific identification. Standard microbiological methods for bovine mastitis diagnosis are time consuming, laborious and prone to errors for some bacteria genera. In our study, we showed that MALDI-TOF MS coupled with Biotyper may be an alternative method for large-scale identification of bacteria isolated from milk samples compared to classical microbiological routine protocols.
\end{abstract}

INDEX TERMS: Rapid identification, bovine mastitis, pathogens, MALDI-TOF MS, Mass Spectrometry, protein fingerprinting, subclinical mastitis, cattle, bacterioses.

\begin{abstract}
RESUMO.- [Rápida identificação de agentes causadores de mastite por espectrometria de massas MALDI-TOF.] A espectrometria de massas (MALDI-TOF MS) tem mostrado ser um método alternativo para a identificação de bactérias, sendo capaz de identificar as bactérias causadoras de mastite em gênero, espécie ou até mesmo subespécie. Com o objetivo
\end{abstract}

\footnotetext{
${ }^{1}$ Received on January 16, 2017.

Accepted for publication on March 23, 2017.

2 Laboratório Thomson de Espectrometria de Massas, Instituto de Química, Universidade Estadual de Campinas (Unicamp), Rua Sérgio Buarque de Holanda s/n, Cidade Universitária, Campinas, SP 13083-859, Brazil.

${ }^{3}$ Departamento de Nutrição e Produção Animal, Faculdade de Medicina Veterinária e Zootecnia, Universidade de São Paulo (USP), Av. Duque de Caxias Norte 225, Pirassununga, SP 13635-900, Brazil. *Corresponding author: mveiga@usp.br
}

de identificar os patógenos causadores de mastite em grande-escala por esta plataforma, um total de 305 isolados bacterianos oriundos de vacas com mastite subclínica foram analisados pela cultura microbiológica convencional (CM) e pela MALDI-TOF MS acoplada ao software Biotyper. Aproximadamente 89\% das identificações realizadas pela MALDI-TOF MS foram consistentes com os resultados obtidos pela CM. Do restante de isolados bacterianos (11\%), 6,3\% foram classificados como identificação errônea (discordância de gênero e espécie), e 4,7\% apresentaram concordância de gênero, mas discordância da espécie. Os resultados que apresentaram divergência estavam mais associados com a identificação das espécies de Streptococcus spp. e Enterococcus spp. devido à similaridade fenotípica entre os dois gêneros. Estes resultados divergentes sugerem que os ensaios bioquímicos podem ser propensos a erros de identificação, por isso a MALDI-TOF MS pode ser 
considerada um método alternativo para superar os erros de identificação da CM. A cultura microbiológica padrão e os ensaios bioquímicos utilizados na identificação de agentes causadores de mastite são demorados, trabalhosos e propensos a erros quando utilizados na identificação em nível de espécie. No presente estudo, demonstramos que a MALDI-TOF MS acoplada ao software Biotyper pode ser considerada um método alternativo de identificação de bactérias causadoras de mastite em grande-escala quando comparado com a cultura microbiológica convencional.

TERMOS DE INDEXAÇÃO: Identificação rápida, mastite, espectrometria de massas, MALDI-TOF MS, perfil proteico, mastite subclínica, bovinos, bacterioses.

\section{INTRODUCTION}

Bovine mastitis is characterized by an inflammation of the mammary gland, which directly affects its physiological function. This disease is one of the most significant health concern in dairy cattle since infected cows have the milk quality and yield altered (Barreiro et al. 2010, Gonçalves et al. 2014, Tomazi et al. 2014). The majority of mastitis cases occur in the subclinical form and may lead to rapid transmission of the infection from infected to healthy cows (Halasa et al. 2007).

Several microorganisms may be isolated from cows with subclinical mastitis. However, a small group of bacteria (Staphylococcus aureus, Streptococcus uberis, Streptococcus dysgalactiae, and Escherichia coli) is responsible for approximately $80 \%$ of mastitis cases (Reis et al. 2011). Corynebacterium spp. and coagulase-negative staphylococci (CNS), although considered minor pathogens, have also been frequently associated with subclinical mastitis (Schukken et al. 2009, Gonçalves et al. 2014). Minor pathogens have been increasingly isolated from milk samples of dairy cows, but routine milk microbiological procedures have not been able to identify these bacteria at the species level in a timely manner.

On average, routine milk microbiological procedures take from 3 to $5 \mathrm{~d}$ to be completed and require the use of various biochemical tests and the need of experienced lab personnel (Barreiro et al. 2010). Due to the difficulty of diagnosis of some microorganisms through conventional MC, mass spectrometry (MS) techniques have increasingly been used for this purpose (Ryzhov \& Fenselau 2001, Bizzini \& Greub 2010, Sogawa et al. 2011, Steensels et al. 2011). Matrix-assisted laser desorption/ionization time-of-flight mass spectrometry (MALDI-TOF MS) has been the technique of choice and extensively employed to microorganism species-level identification, and is emerging as an alternative method for microorganism identification due to high accuracy and fast procedures (Fenselau \& Demirev 2001, Dubois et al. 2010, Sogawa et al. 2011). MALDI-TOF MS microorganism identification has already been applied worldwide in routine analysis in many clinical microbial laboratories for fast and reliable diagnostics (Bizzini \& Greub 2010, Steensels et al. 2011, Welker 2011, Braga et al. 2013).

The identification of most prevalent mastitis causing pathogens such as Staphylococcus aureus, Corynebacterium spp. and CNS by the technique of MALDI-TOF MS has been reported and the workflow optimized by our group (Barreiro et al. 2010, Gonçalves et al. 2014, Tomazi et al. 2014). However, recent evidence suggests that a group of environmental streptococci and streptococci-like bacteria, which include bovine mastitis pathogenic Streptococcus, Enterococcus, Lactococcus and Aerococcus species are prone to misidentification by biochemical assays (Werner et al. 2014).

The difficulty of correct identification of environmental streptococci and streptococci-like bacteria from bovine mastitis has been only possible through the application of modern molecular taxonomic approaches, meaning that these genera are closely linked (Werner et al. 2014). Thus, their identification by conventional MC is not trivial, resulting in misidentification of isolates at the genera and species levels (Hardie \& Whiley 1997, Santos et al. 2007). On the other hand, for mastitis etiology the use of molecular methods is still costly to be routinely used.

The applicability of MALDI-TOF MS to identify microorganisms has been suggested since 2001 (Ryzhov \& Fenselau 2001) and by our group (Barreiro et al. 2010, Gonçalves et al. 2014, Tomazi et al. 2014) and others. However, no previous studies have investigated the use of MALDI-TOF MS in a large scale manner in a milk quality laboratory routine for identification of subclinical mastitis causing pathogens. In this context, the aim of this study was to identify microorganisms causing bovine mastitis in a fast and reliable manner by MALDI-TOF MS and compare these results to the conventional MC assays.

\section{MATERIALS AND METHODS}

Milk samples collection. Milk samples were collected from 305 mammary quarters of 77 dairy cows previously diagnosed with subclinical mastitis from 13 dairy farms in São Paulo State, Brazil. Milk samples were collected aseptically according to the recommendations of the National Mastitis Council (Oliver et al. 2004) (NMC) and transported at $4.5^{\circ} \mathrm{C}$ to laboratory for further analysis. The study agreed with Ethical Principles in Animal Research adopted by "Ethical Committee in the Use of Animals" of the School of Veterinary Medicine and Animal Science of University of São Paulo, which was registered by the following protocol numbers: 2418/2011, 2231/2011 and 2237/2011.

Microbiological culture. Isolation and identification of the mastitis causing pathogens were performed according to the methodology proposed by NMC (Murray et al. 2003, Oliver et al. 2004). Approximately $10 \mu \mathrm{L}$ of milk were inoculated onto blood agar plate $^{\text {a }}$ (containing $5 \%$ of bovine blood) with the aid of a calibrated platinum loop. The plates were aerobically incubated at $37^{\circ} \mathrm{C}$ and checked at 24, 48 and 72 hours after inoculation for the presence of bacterial growth. After the incubation period, bacterial colonies were classified according to their morphological features (color, appearance, size and presence of hemolysis). The isolates were Gram stained and differentiated at the species or group level by biochemical tests ${ }^{\mathrm{b}}$ (Table 1 and 2). Specifically, Corynebacterium spp. were identified as a single small, circular colony (approximately $1 \mathrm{~mm}$ in diameter) with a white-gray or yellowish color and a slightly raised, dry and/or flaky, and nonhemolytic appearance once biochemical tests ${ }^{\mathrm{b}}$ for its species identification have been not recommended (Goncalves et al. 2014 , Oliver et al. 2004). Isolates were stored at $-20^{\circ} \mathrm{C}$ in $1 \mathrm{~mL}$ of brain heart infusion broth ${ }^{\mathrm{a}}$ supplemented with $2 \%$ glycerin $^{\mathrm{c}}$ until analysis by MALDI-TOF MS.

Considering that Corynebacterium spp. requires special culture needs, isolates were transferred to trypticase soy agar ${ }^{\text {a }}$ (TSA) supplemented with $1 \%$ polysorbate ${ }^{d}$ to enhance the growth of these microorganisms, which require fatty acid supplementation for growth (Huxley et al. 2004). For that reason, Corynebacterium spp. 
isolates were maintained at $-20^{\circ} \mathrm{C}$ in $1 \mathrm{~mL}$ of trypticase soy broth ${ }^{\text {a }}$ (TSB) supplemented with $10 \%$ glycerinc.

Sample preparation and MALDI-TOF MS measurements. For MALDI-TOF MS sample preparation, bacterial strains isolated from milk were thawed and cultured for $24 \mathrm{~h}$ in a $\mathrm{BHI}^{\mathrm{a}}$ broth. After the incubation period, bacterial culture was centrifuged, inactivated in $75 \%$ ethanol ${ }^{e}$ HPLC grade, and submitted to bacterial extraction, as previously described (Barreiro et al. 2010). Briefly, microtubes containing the isolated bacteria inactivated in $75 \%$ ethanole solution were centrifuged at $13,000 \times g$ for $2 \mathrm{~min}$, and the supernatant was removed by carefully pouring it out from the microtube. A second centrifugation step was performed and the remaining liquid was carefully removed with a pipette tip. After drying the pellets for approximately 15 minutes, a solution of $70 \%$ formic acid ${ }^{\mathrm{f}}$ was added proportionally to the size of pellet to completely dissolve it in order to lyse bacterial cells and release mainly the ribosomal proteins, which represent the characteristic fingerprinting used for MALDI-TOF MS-based identification (Ryzhov \& Fenselau 2001). After that, the same volume of pure acetonitrile $\mathrm{e}^{\mathrm{e}}$ HLC grade was added to the amount of $70 \%$ formic acid ${ }^{\mathrm{f}}$ solution previously used, producing a bacterial extract in a $1: 1(\mathrm{v} / \mathrm{v})$ ratio of acetonitrile $\mathrm{e} /$ formic acid ${ }^{\mathrm{f}}$. After, the solution was centrifuged $(13,000 \times g$ for $2 \mathrm{~min})$ to separate the bacterial cells debris from the supernatant containing bacterial proteins. MALDI-TOF MS analyses were performed in a Bruker Autoflex Smart Beam III equipment ${ }^{\mathrm{g}}$ operated in the linear mode and equipped with a 337-nm nitrogen laser. FlexControl 3.3 software $^{g}$ was used to obtain the mass spectra, which were acquired within a range $(\mathrm{m} / \mathrm{z})$

Table 1. Summary of steps used for identification of bacteria of the genus Staphylococcus

\begin{tabular}{cccc}
\hline \multirow{2}{*}{ Biochemical tests } & \multicolumn{3}{c}{ Staphylococcus spp. } \\
\cline { 2 - 4 } Morphology & S. aureus & CPS non-aureus ${ }^{\text {a }}$ & CNS $^{\text {b }}$ \\
\hline (cocci) & grape-like & clusters & $\begin{array}{c}\text { grape-like } \\
\text { clusters }\end{array}$ \\
Gram staining & + & + & + \\
KOH & - & - & - \\
Catalase & + & + & + \\
Coagulase & + & + & - \\
Acetoin & + & - & -
\end{tabular}

${ }^{a}$ Coagulase Positive Staphylococci non-aureus: the most subclinical cases were caused by $S$. hyicus and $S$. intermedius, ${ }^{\text {b }}$ Coagulase Negative Staphylococci. Adapted from Oliver et al. (2004). of 2,000 to 20,000. Each spectrum resulted from the accumulation of at least 240 laser shots obtained from 10 different regions of the same sample spot. Before analyses, external calibration of the equipment was performed with a Bacterial Test Standard Calibrant Mixture $^{g}$ (BTS), covering the mass range between 2,000 and 20,000 Da. The BTS ${ }^{g}$ was an Escherichia coli extract including the additional proteins RNase A and myoglobin. An extract of Escherichia coli (ATCC 25922) was also used as reference sample in order to check the calibration previously performed. To prepare the MALDI target plate, $1 \mu \mathrm{L}$ of each bacterial extract was manually deposited onto a 384-spot stainless steel plate and allowed to dry at room temperature. After air-drying, each sample was overlaid with $1 \mu \mathrm{L}$ of saturated $\alpha$-cyano-4-hydroxycinnamic acid matrix solution and left at room temperature for drying completely. Sample identification was performed in an automated manner through the MALDI Biotyper Real Time Classification 3.0 tool $^{\mathrm{g}}$. The result was provided by means of a log score with a maximum value of 3.0. Score values higher than 1.7 were considered reliable for genus identification, and scores higher than 2.0 were considered probable for species identification (Barreiro et al. 2010). Isolates, which presented identification in disagreement between both methods, were called misidentified (MI). On the other hand, isolates with identification agreement at genus level but not at species level by both identification methods were classified as unidentified (UI) (Gonçalves et al. 2014).

The microorganism species-specific identification provided by biochemical assays as a gold standard was compared with the results of MALDI-TOF MS, thus providing the frequency of diagnosis equivalence between the two methods.

\section{RESULTS}

MALDI-TOF MS coupled to the Biotyper version 3.0 was used to analyze 305 isolates from milk samples of dairy cows with subclinical mastitis. The same isolates were identified by conventional MC methodology. From 305 bacterial isolates, 297 were identified by MALDI-TOF MS with score values higher than 2.0, ensuring both genus and species identification. From the remaining eight strains, four were identified with scores values between 1.7 and 2, which ensures only the identification at the genus level. Although the low score values do not ensure the secure identification at the bacterial species level for these four strains, the species suggested by MALDI-TOF MS were two Staphylococcus chromogenes, one Staphylococcus pasteuri and one Staphylococcus haemolyticus. These isolates are species of CNS and presented concordance

Table 2. Summary of steps used for identification of bacteria of the genus Streptococcus and Enterococcus

\begin{tabular}{|c|c|c|c|c|c|}
\hline \multirow{2}{*}{ Biochemical tests } & \multicolumn{4}{|c|}{ Streptococcus spp. } & \multirow{2}{*}{ Enterococcus spp. } \\
\hline & S. agalactiae & S. dysgalactiae & S. uberis & S. bovis & \\
\hline Morphology (cocci) & $\begin{array}{l}\text { tendency to form } \\
\text { chains }\end{array}$ & single or short chains & short chains & pairs or chains & $\begin{array}{c}\text { singles, pairs } \\
\text { (diplococci) or short } \\
\text { chains }\end{array}$ \\
\hline Gram staining & + & + & + & + & + \\
\hline $\mathrm{KOH}$ & - & - & - & - & - \\
\hline Catalase & - & - & - & - & - \\
\hline CAMP & + & - & $+/-$ & - & - \\
\hline Esculin & - & $+/-$ & + & + & + \\
\hline Bile esculin & - & - & - & + & + \\
\hline Pyr test & - & - & + & - & + \\
\hline
\end{tabular}

$\overline{\text { Adapted from Murray et }}$ al. (2003) and Oliver et al. (2004). 
with MC results. The MALDI-TOF MS identification of another set of four isolates was not possible. Even though good quality mass spectra were acquired, these spectra were therefore unmatched with those available in the database. Approximately $89 \%(n=264$ isolates) of the identifications performed by MALDI-TOF MS were consistent with the results obtained from the identification of microorganisms by MC at both genus and species levels (Table 3).

Therefore, MALDI-TOF MS correctly identified 119 isolates as Staphylococcus aureus, 37 as CNS 26 S. chromogenes, 3 S. epidermidis, 1 S. felis, 1 S. hominis, 1 S. saprophyticus, 4 S. simulans and 1 S. xylosus), 33 as Streptococcus agalactiae, 26 as Streptococcus uberis, 1 as Streptococcus dysgalactiae, and 48 bacteria isolates were identified as Corynebacterium bovis. For all analyzed isolates, the second microorganism suggested by the Biotyper software was in agreement with the first one. Another aspect, which adds to the results accuracy, is that, in most instances, the software may not give a second option for those identified microorganism. Protein profiles of isolates from milk samples and their identification by MALDI-TOF MS Biotyper data processing can be observed in the Figures 1 to 3.

From the 297 isolates, 33 isolates (11\%) showed discordant results between MALDI-TOF MS and biochemical assays (Table 3). From 33 strains in disagreement, 19 (6.3\%) isolates were classified as misidentified (MI) since the results between both methods of identification were in discordance for both genus and species level. However, 14 isolates (4.7\%) showed identification agreement at the genus level but not at the species level (Table 3), being classified as unidentified at species level (UI). The disagreement results were mostly associated with identification of Streptococcus and Enterococcus species, probably due to the narrow phenotypic similarity between these two genera, leading most likely to misidentification by the morphological assays. Isolates classified as MI and UI were re-analyzed by MALDI-TOF MS and MC.

Table 3. Identification results of bacterial strains obtained by MALDI-TOF MS plus Biotyper data processing versus the classical microbiological culture methodology

\begin{tabular}{|c|c|c|c|c|c|}
\hline \multicolumn{2}{|l|}{ MALDI-TOF MS } & \multicolumn{2}{|l|}{ Microbiological culture } & \multicolumn{2}{|c|}{ Discordant results } \\
\hline $\begin{array}{c}\text { Correctly identified at species level } \\
(\text { scores } \geq 2)\end{array}$ & $n^{1}$ & Bovine mastitis-causing pathogens & $n^{2}$ & $\mathrm{MI}^{\mathrm{a}}$ & $\mathrm{UI}^{\mathrm{b}}$ \\
\hline Staphylococcus aureus & 119 & Staphylococcus aureus & 119 & 0 & 0 \\
\hline Staphylococcus hyicus & 2 & $\mathrm{CPS}^{\mathrm{c}}$ non-aureus & 0 & 0 & 2 \\
\hline Coagulase-negative staphylococci & 37 & Coagulase-negative staphylococci & 37 & 0 & 0 \\
\hline Streptococcus agalactiae & 33 & Streptococcus agalactiae & 33 & 0 & 0 \\
\hline Streptococcus uberis & 1 & Streptococcus agalactiae & 0 & 0 & 1 \\
\hline Streptococcus dysgalactiae & 1 & Streptococcus agalactiae & 0 & 0 & 1 \\
\hline Streptococcus dysgalactiae & 1 & Streptococcus dysgalactiae & 1 & 0 & 0 \\
\hline Enterobacter cloacae & 4 & Streptococcus dysgalactiae & 0 & 4 & 0 \\
\hline Enterococcus faecalis & 7 & Streptococcus dysgalactiae & 0 & 7 & 0 \\
\hline Streptococcus agalactiae & 4 & Streptococcus dysgalactiae & 0 & 0 & 4 \\
\hline Streptococcus suis & 1 & Streptococcus dysgalactiae & 0 & 0 & 1 \\
\hline Streptococcus uberis & 26 & Streptococcus uberis & 26 & 0 & 0 \\
\hline Enterococcus casseliflavus & 2 & Streptococcus uberis & 0 & 2 & 0 \\
\hline Enterococcus faecalis & 1 & Streptococcus uberis & 0 & 1 & 0 \\
\hline Lactococcus garviae & 2 & Streptococcus uberis & 0 & 2 & 0 \\
\hline Lactococcus lactis & 1 & Streptococcus uberis & 0 & 1 & 0 \\
\hline Streptococcus agalactiae & 2 & Streptococcus uberis & 0 & 0 & 2 \\
\hline Streptococcus dysgalactiae & 2 & Streptococcus uberis & 0 & 0 & 2 \\
\hline Streptococcus pluranimalium & 1 & Streptococcus uberis & 0 & 0 & 1 \\
\hline Corynebacterium bovis & 48 & Corynebacterium spp. & 48 & 0 & 0 \\
\hline Arthrobacter globiformis & 1 & Corynebacterium spp. & 0 & 1 & 0 \\
\hline Arthrobacter oxydans & 1 & Corynebacterium spp. & 0 & 1 & 0 \\
\hline Subtotal & 297 & & 264 & 19 & 14 \\
\hline $\begin{array}{l}\text { Correctly identified at species level } \\
\text { (scores of 1.7-2) }\end{array}$ & $n^{1}$ & Bovine mastitis-causing pathogens & $n^{2}$ & $M I^{\mathrm{a}}$ & $\mathrm{UI}^{\mathrm{b}}$ \\
\hline Coagulase-negative staphylococci & 4 & Coagulase-negative staphylococci & 4 & 0 & 0 \\
\hline Subtotal & 4 & & 4 & 0 & 0 \\
\hline Total & 301 & & 268 & 19 & 14 \\
\hline
\end{tabular}

$\overline{{ }^{a} \mathrm{MI}=\text { misidentified, }{ }^{\mathrm{b}} \mathrm{UI}=\text { unidentified, }}{ }^{\mathrm{c}}$ Coagulase-positive staphylococci; $n^{1}=$ number of isolates identified by MALDI-TOF MS, $n^{2}=$ number of isolates identified by microbiological culture. 


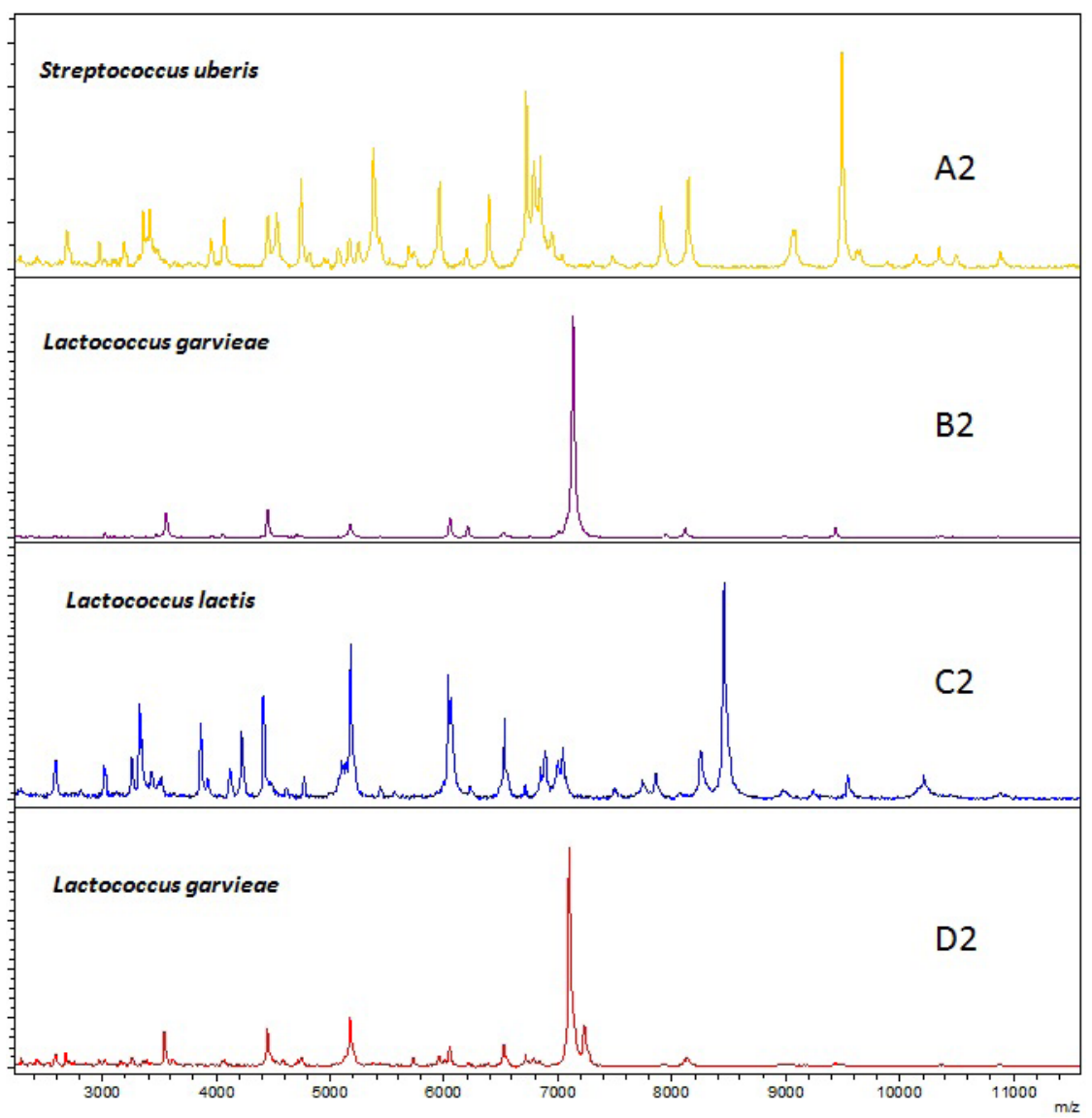

Fig.1. MALDI-TOF MS spectra for four bacteria isolates from milk samples and their identification by Biotyper data processing. Note that all isolates were identified by the conventional microbiological culture analysis as Streptococcus uberis.

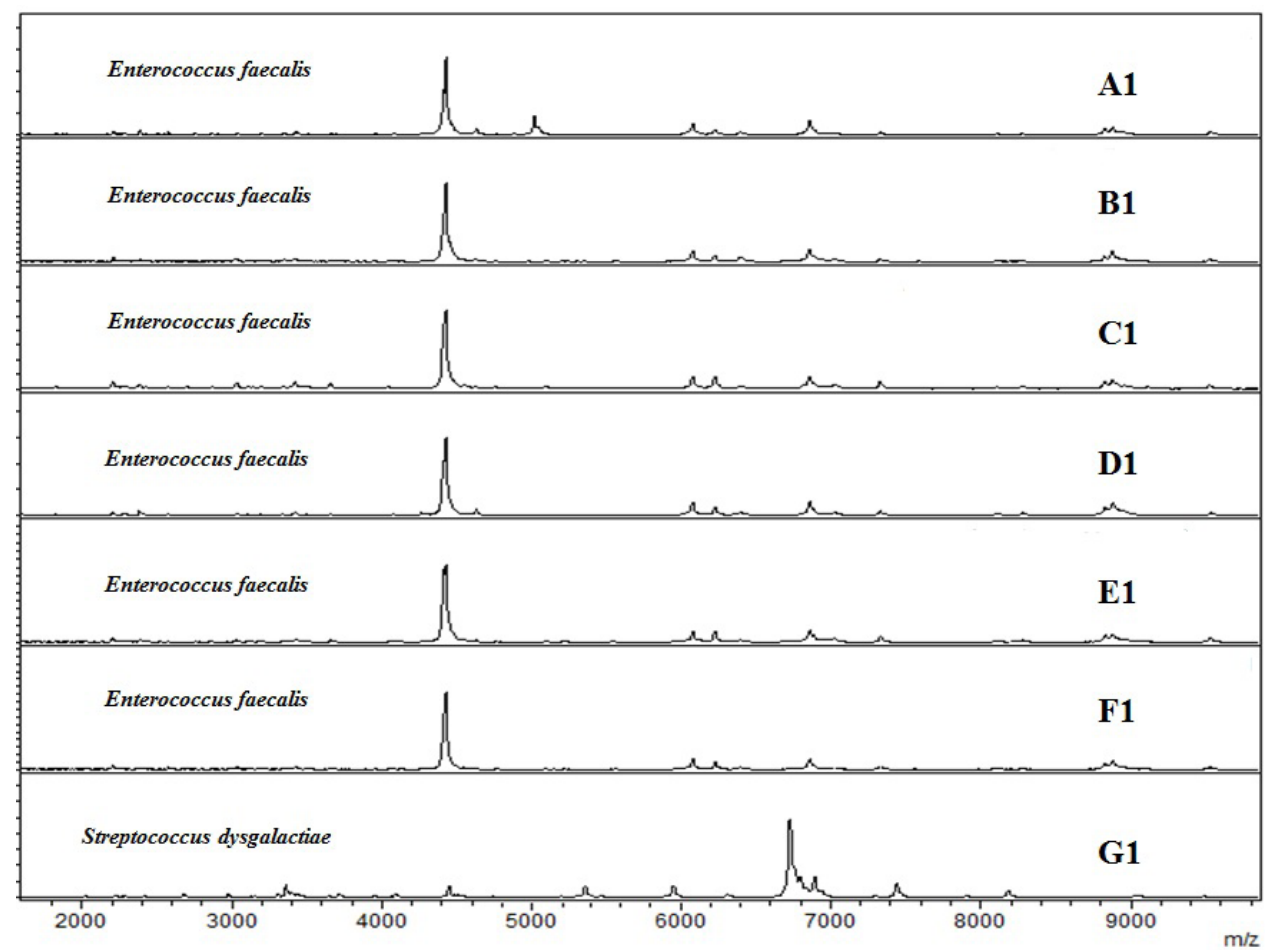

Fig.2. MALDI-TOF MS spectra showing protein profiles of seven bacteria isolates from milk samples and their identification by Biotyper data processing. Note that all isolates were identified by the conventional microbiological culture analysis as Streptococcus dysgalactiae. 


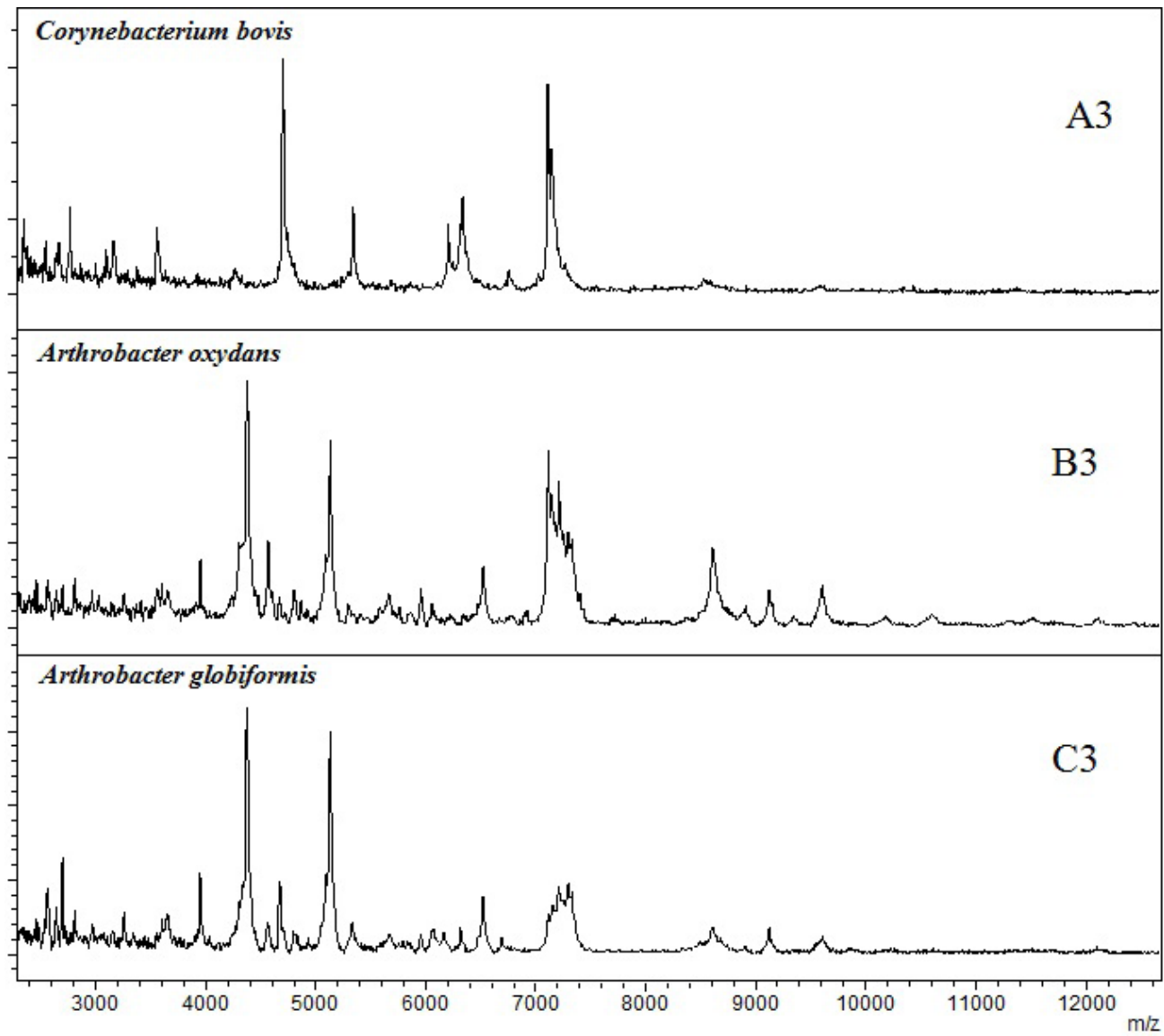

Fig.3. MALDI-TOF MS spectra of three bacterial isolates from milk of cows with subclinical mastitis, and their identification by Biotyper data processing. Note that all isolates were identified by the conventional microbiological culture analysis as Corynebacterium bovis. The protein profiles for Arthrobacter oxydans and Arthrobacter globiformis are more closely related than that for Corynebacterium bovis.

\section{DISCUSSION}

This study aimed to identify microorganisms causing bovine mastitis in a fast and reliable manner by MALDI-TOF MS and compare these results to the conventional MC assays. A total of 264 (89\%) isolates analyzed by MALDI-TOF MS and Biotyper data processing showed results consistent with those obtained by MC (Table 3). Additionally, considering that we had $11 \%$ of discordant results, it was not possible to determine which methodology was more reliable, because both MALDI-TOF and MC have limitations, which would demand a gold standard method such as DNA sequencing for confirmation of the results.

In agreement with MC results, MALDI-TOF MS correctly identified all 119 Staphylococcus aureus isolates. Additionally, two isolates which were coagulase positive and acetoin negative in the MC assay were classified as Staphylococcus hyicus by MALDI-TOF MS. These results are similar to those reported by other study, in which isolates of Staphylococcus were 99.3\% correctly identified by MALDI-TOF MS (Dubois et al. 2010), suggesting that MALDI-TOF MS associated with Biotyper software is an excellent alternative to traditional methods for the identification of Staphylococcus species.
The MC identified 41 microorganisms as CNS but was not able to identify the isolates at the species level. On the other hand, when these CNS isolates were analyzed by MALDI-TOF MS, the following species were identified: Staphylococcus chromogenes $(\mathrm{n}=26)$, Staphylococcus simulans $(\mathrm{n}=4)$, Staphylococcus epidermidis $(\mathrm{n}=3)$, Staphylococcus felis $(\mathrm{n}=1)$, Staphylococcus hominis $(\mathrm{n}=1)$, Staphylococcus saprophyticus $(\mathrm{n}=1)$ and Staphylococcus xylosus $(\mathrm{n}=1)$. Four additional isolates were identified by MALDI-TOF MS only at the genus level, totaling 41 CNS isolates. The rRNA sequencing was not performed, but according to previous studies, this result shows agreement with the fact that more than ten different CNS have been isolated from milk of cows with subclinical mastitis and the most frequently identified species are $S$. simulans and S. chromogenes (Thorberg et al. 2006, Tomazi et al. 2014). MALDI-TOF MS properly identified 37 out of 41 CNS isolates $(90.2 \%)$ at species level and the remaining four isolates were identified as CNS with scores values between 1.7 and 2 . These results are in accordance with recent studies indicating that MALDI-TOF MS is a reliable alternative method for differentiating $>90 \%$ of CNS species causing bovine subclinical mastitis (Tomazi et al. 2014). 
Microorganisms belonging to Streptococcus genus, such as Streptococcus agalactiae, Streptococcus dysgalactiae and Streptococcus uberis, are one of the main bacteria genera isolated from bovine mastitis and are considered the major cause of subclinical mastitis in dairy cows (Keefe 1997, Leigh 1999, Erskine et al. 2003). Considering the Streptococcus species isolated in our study, 33 out of 35 isolates (94.3\%) were correctly identified by both methodologies as Streptococcus agalactiae. This result seem to be consistent with other studies which found that $>99 \%$ of Streptococcus agalactiae isolates were correctly identified by MALDI-TOF MS (Lartigue et al. 2009). Two isolates of Streptococcus agalactiae identified by MC had probably different identification by MALDI-TOF MS due to the erroneous interpretation of the esculin test. Using the $\mathrm{MC}$ identification did not exclude the possibility of certain strains of Streptococcus agalactiae may show a variable result (i.e. Streptococcus agalactiae esculin positive). On the other hand, phenotypic and biochemical identification methods can be inaccurate and unreliable for identification of a large and closely related group of environmental streptococci and streptococci-like bacteria (Werner et al. 2014). As a matter of fact, this finding may explain that the majority of the discordant results $(\mathrm{n}=17)$ belonged to isolates of the Streptococcus, Lactococcus and Enterococcus genus.

A total of 26 out of 37 isolates (70.3\%) were identified in the present study by both methodologies as Streptococcus uberis, which further support that approximately 30\% of Streptococcus uberis $(\mathrm{n}=11)$ identified by MALDI-TOF MS did not show concordance to the identification by MC. Regarding misidentification among species from the environmental streptococci group and streptococci-like bacteria, six isolates identified as Streptococcus uberis by MC were identified as Enterococcus casseliflavus $(\mathrm{n}=2)$, Enterococcus faecalis $(\mathrm{n}=1)$, Lactococcus garviae $(\mathrm{n}=2)$ and Lactococcus lactis $(\mathrm{n}=1)$ by MALDI-TOF MS MC. The other five isolates were considered unidentified, because they had identification agreement at the genus level but not at the species level. Three isolates of Streptococcus uberis identified by MC had different identification by MALDI-TOF MS (Enterococcus spp.) due to the negative result of the bile esculin test. In a previous study, 11 out of 48 isolates (22.9\%) identified as Streptococcus spp. by MC were identified as Enterococcus spp. by sequence analysis of 16SrDNA and rpoB genes (Werner et al. 2014). These findings raise intriguing questions regarding the nature and extent of streptococci-like bacteria causing mastitis. In addition, three isolates that were identified as Streptococcus uberis using MC were identified by MALDI-TOF MS as belonging to the Lactococcus genus (Fig.1). A possible explanation for this might be that neither National Mastitis Council ${ }^{23}$ (NMC) guidelines nor commercially available biochemical test kits have included Lactococcus genus as a relevant pathogen causing bovine mastitis. Thus, it is possible that the frequency of Lactococcus spp. associated with bovine mastitis has been underreported (Werner et al. 2014).

Figure 1 shows spectra of four strains identified as Streptococcus uberis by MC. According to MALDI-TOF MS results, only one isolate showed protein profile consistent with Streptococcus uberis (A2). The remaining three isolates showed a comparable fingerprinting with the genus Lactococcus. However, the role of Lactococcus genus as a cause of bovine intramammary infection is still not clear (Werner et al. 2014).
Another important finding was that only one out of 17 isolates (5.9\%) was identified by both methodologies as Streptococcus dysgalactiae. From the remaining 16 isolates identified as Streptococcus dysgalactiae by traditional methods, 11 of them were classified as misidentified and 5 were unidentified, whereas MALDI-TOF MS identified 11 Enterococcus spp. and 5 different species of Streptococcus. Misidentification of Streptococcus dysgalactiae may be common in small percentage, because esculin test results is variable and Streptococcus dysgalactiae subsp. equisimilis (Lancefield Group A,C,G,L) are beta-hemolytic, but Streptococcus dysgalactiae subsp. dysgalactiae (Lancefield Group C) are not beta-hemolytic (Murray et al. 2003). Additionally, to correctly differentiate Streptococcus dysgalactiae from others streptococci-like bacteria it may be necessary to use serological kits or biochemical tests (test e.g. growth in $6.5 \% \mathrm{NaCl}$ ), which is costly and time-consuming.

Figure 2 shows one representative MALDI-TOF MS spectra of the Streptococcus dysgalactiae (G1) correctly identified by MC. Isolates from $\mathrm{A} 1$ to $\mathrm{F} 1$, identified as Streptococcus dysgalactiae through MC, were identified as Enterococcus genus by MALDI-TOF MS. Comparing the protein profile obtained for these isolates, it is possible to observe that there is no chemical similarity with isolate G1 previously identified as Streptococcus dysgalactiae for both methodologies.

Due to morphological similarity between Streptococcus, Lactococcus, Aerococcus and Enterococcus, possible misidentification (Pyr test) or erroneous interpretation (esculin and bile esculin test results may be variable, Table 2) through biochemical tests may have occurred. In addition, twelve out of 89 (13.5\%) Streptococcus spp. isolates were possibly considered unidentified because there were erroneous interpretation of biochemical tests results. These few isolates represented only $4 \%$ of all isolates evaluated and these few failures occurred in the Streptococcus spp. identification at species level by MC.

Minor pathogens such as Corynebacterium spp. were also identified in this study. Corynebacterium spp. are difficult to identify at the species level since these microorganisms share phenotypic similarities with other bacteria and require numerous biochemical tests in order to be properly identified by MC (Bernard 2005). This genus has been increasingly isolated in cases of subclinical mastitis and its identification is challenging, which may lead to incorrect genus classification by MC. Corynebacterium bovis and CNS species are the most predominant isolated bacteria from cows with subclinical mastitis, which indicates the importance of correct genus and species identification of these bacteria (Bexiga et al. 2011). From 50 isolates, which were previously identified as Corynebacterium spp. by MC, 48 (96\%) were identified by MALDI-TOF MS as Corynebacterium bovis and two isolates were identified as belonging to the Arthrobacter genus (Arthrobacter globiformis and Arthrobacter oxydans). Bacteria belonging to the Arthrobacter genus have been not often isolated from cows with clinical and subclinical mastitis. These microorganisms have been manly found in soils of different geographical locations; therefore suggesting a contamination of these milk samples even though morphological similarities occur between these genera (Olson et al. 1992, Jones \& Keddie 2006).

In fact, in the past, some authors considered that bacteria from Arthrobacter genus should be classified into the Corynebacterium genus due to the morphological similarities 
among them. Arthrobacter were originally described as being highly aerobic, nutritionally non-exacting and capable of liquefying gelatin slowly, but the attempt to distinguish species from Arthrobacter and Corynebacterium genus through biochemical characteristics failed because of its poor circumscription and the genus Arthrobacter was included into the Corynebacteriaceae family (Jones \& Keddie 2006). Fortunately, MALDI TOF MS was able to distinguish these two genera through protein fingerprinting, whereas two strains were misidentified by the conventional methodology. Figure 3 shows the protein profile obtained for Corynebacterium bovis strain compared with spectra achieved for two strains identified as Arthrobacter genus.

Indeed, as already pointed out from previous reports on human clinical isolates (Carbonnelle et al. 2011, Croxatto et al. 2012, Suarez et al. 2013), MALDI-TOF MS was shown to be a faster and more accurate technique for the identification of bacteria isolated from milk samples compared to classical microbiological routine protocols. When tested again on a large and diverse set, this protocol allowed us to evaluate and identify a great number of strains in a quickly, reliably and reproducible manner. The vast majority of the isolates identified in this study were Staphylococcus aureus species (39\%; $n=119$ ). Such results corroborate previous studies showing that Staphylococcus aureus is one of the predominant causes of subclinical mastitis (Reis et al. 2011, Lee et al. 2012). In addition, minor pathogens (Corynebacterium spp. and CNS) are frequent causes of bovine subclinical mastitis and their identification by conventional MC is laborious, costly and prone to errors. Besides that, $\mathrm{MC}$ only allows the identification of Corynebacterium spp. and CNS at genus level. Using MALDI/Biotyper technique, it was possible to identify these groups of microorganisms at the species level.

The molecular methods (e.g. DNA sequencing) could have been performed for the $11 \%$ of discordant results $(n=33$ isolates) found between both used methods. Although data obtained in the present study suggest that identification by MALDI-TOF MS was more accurate than the conventional method, molecular methods would be the last resource to confirm the identification of the discordant results. However, a previous study that evaluated molecular methods had already reported failures in the identification of Streptococcus spp. causing mastitis (Werner et al. 2014). Furthermore, our objective was to investigate the use of MALDI-TOF MS in a large-scale manner in a milk quality laboratory routine for identification of subclinical mastitis causing pathogens and for this reason, molecular analyses was not performed in our study. Therefore, the decision of not using molecular methods may be interpreted as a limitation of the current study. Another topic is the applicability of MALDI-TOF MS for identification of Gram-negative pathogens that was not evaluated in the present study, because we did not isolate these pathogens causing subclinical mastitis. This applicability has been assessed for identification of bacterial strains routinely isolated in a clinical microbiology laboratory (Bizzini et al. 2010). The successfully adoption of MALDI-TOF MS to milk microbiology routine depends on the completeness of the mastitis causing pathogens database of Biotyper software.

\section{CONCLUSION}

MALDI-TOF MS coupled with Biotyper data processing may be considered an alternative tool for routinely identification of subclinical mastitis pathogens in large scale in milk samples once it showed to be faster and accurate method.

Conflict of interest statement.- The author(s) declare(s) that there is no conflict of interest.

Acknowledgments.- The authors are grateful to Fundação de Amparo à Pesquisa do Estado de São Paulo (FAPESP), Brazil, for their financial support and for the scholarship awarded (2011/01867-2).

Sources and manufactures.- a) Becton, Dickinson and Company, Sparks, MD, USA; b) Laborclin Ltda., Pinhais, PR, Brazil; c) Labsynth, Diadema, SP, Brazil; d) Tween 80, Sigma, St. Louis, MO, USA; e) J.T. Baker, Mallinckrodt Baker, NJ, USA; f) Sigma-Aldrich, Saint Louis, MO, USA; g) Bruker Daltonik, Bremen, Germany.

\section{REFERENCES}

Barreiro J.R., Ferreira C.R., Sanvido G.B., Kostrzewa M., Maier T., Wegemann B., Böttcher V., Eberlin M.N. \& Santos M.V. 2010. Short communication: identification of subclinical cow mastitis pathogens in milk by matrixassisted laser desorption/ionization time-of-flight mass spectrometry. J. Dairy Sci. 93(12):5661-5667. http://dx.doi.org/10.3168/jds.2010-3614. PMid:21094737.

Bernard K. 2005. Corynebacterium species and coryneforms: an update on taxonomy and diseases attributed to these taxa. Clin. Microbiol. Newsl. 27(2):9-18. http://dx.doi.org/10.1016/j.clinmicnews.2005.01.002.

Bexiga R., Pereira H., Pereira O., Leitão A., Carneiro C., Ellis K.A. \& Vilela C.L. 2011. Observed reduction in recovery of Corynebacterium spp. from bovine milk samples by use of a teat cannula. J. Dairy Res. 78(1):9-14. http:// dx.doi.org/10.1017/S0022029910000609. PMid:20822566.

Bizzini A. \& Greub G. 2010. Matrix-assisted laser desorption ionization time-of-flight mass spectrometry, a revolution in clinical microbial identification. Clin. Microbiol. Infect. 16(11):1614-1619. http://dx.doi. org/10.1111/j.1469-0691.2010.03311.x. PMid:20636422.

Bizzini A., Durussel C., Bille J., Greub G. \& Prod'hom G. 2010. Performance of matrix-assisted laser desorption ionization-time of flight mass spectrometry for identification of bacterial strains routinely isolated in a clinical microbiology laboratory. J. Clin. Microbiol. 48(5):1549-1554. http://dx.doi.org/10.1128/JCM.01794-09. PMid:20220166.

Braga P.A.C., Tata A., Gonçalves dos Santos V., Barreiro J.R., Schwab N.V., Veiga dos Santos M., Eberlin M.N. \& Ferreira C.R. 2013. Bacterial identification: from the agar plate to the mass spectrometer. RSC Advances 3(4):9941008. http://dx.doi.org/10.1039/C2RA22063F.

Carbonnelle E., Mesquita C., Bille E., Day N., Dauphin B., Beretti J.L., Ferroni A., Gutmann L. \& Nassif X. 2011. MALDI-TOF mass spectrometry tools for bacterial identification in clinical microbiology laboratory. Clin. Biochem. 44(1):104-109. http://dx.doi.org/10.1016/j.clinbiochem.2010.06.017. PMid:20620134.

Croxatto A., Prod'hom G. \& Greub G. 2012. Applications of MALDI-TOF mass spectrometry in clinical diagnostic microbiology. FEMS Microbiol. Rev. 36(2):380-407. http://dx.doi.org/10.1111/j.1574-6976.2011.00298.x. PMid:22092265.

Dubois D., Leyssene D., Chacornac J.P., Kostrzewa M., Schmit P.O., Talon R., Bonnet R. \& Delmas J. 2010. Identification of a variety of Staphylococcus species by matrix-assisted laser desorption ionization-time of flight mass spectrometry. J. Clin. Microbiol. 48(3):941-945. http://dx.doi.org/10.1128/ JCM.00413-09. PMid:20032251. 
Erskine R.J., Wagner S. \& DeGraves F.J. 2003. Mastitis therapy and pharmacology. Vet. Clin. N. Am., Food Anim. Pract. 19(1):109-138, vi. http://dx.doi. org/10.1016/S0749-0720(02)00067-1. PMid:12682938.

Fenselau C. \& Demirev P.A. 2001. Characterization of intact microorganisms by MALDI mass spectrometry. Mass Spectrom. Rev. 20(4):157-171. http:// dx.doi.org/10.1002/mas.10004. PMid:11835304.

Gonçalves J.L., Tomazi T., Barreiro J.R., Braga P.A., Ferreira C.R., Araújo Junior J.P., Eberlin M.N. \& Santos M.V. 2014. Identification of Corynebacterium spp. isolated from bovine intramammary infections by matrix-assisted laser desorption ionization-time of flight mass spectrometry. Vet. Microbiol. 173(1/2):147-151. http://dx.doi.org/10.1016/j.vetmic.2014.06.028. PMid:25086477.

Halasa T., Huijps K., Osteras O. \& Hogeveen H. 2007. Economic effects of bovine mastitis and mastitis management: a review. Vet. Q. 29(1):18-31. http://dx.doi.org/10.1080/01652176.2007.9695224. PMid:17471788.

Hardie J.M. \& Whiley R.A. 1997. Classification and overview of the genera Streptococcus and Enterococcus. J. Appl. Microbiol. 83(S1):1S-11S. http:// dx.doi.org/10.1046/j.1365-2672.83.s1.1.x. PMid:28621895.

Huxley J.N., Helps C.R. \& Bradley A.J. 2004. Identification of Corynebacterium bovis by endonuclease restriction analysis of the 16S rRNA gene sequence. J Dairy Sci. 87(1):38-45. http://dx.doi.org/10.3168/jds.S0022-0302(04)731392. PMid:14765808.

Jones D. \& Keddie R. 2006. The genus arthrobacter, p.945-960. In: Dworkin M., Falkow S., Rosenberg E., Schleifer K-H. \& Stackebrandt E. (Eds), The Prokaryotes. Springer, New York. http://dx.doi.org/10.1007/0-387. 30743-5_36.

Keefe G.P. 1997. Streptococcus agalactiae mastitis: a review. Can. Vet. J. 38(7):429-437. PMid:9220132.

Lartigue M.-F., Héry-Arnaud G., Haguenoer E., Domelier A.-S., Schmit P.-O., Van der Mee-Marquet N., Lanotte P., Mereghetti L., Kostrzewa M. \& Quentin R. 2009. Identification of Streptococcus agalactiae isolates from various phylogenetic lineages by matrix-assisted laser desorption ionization-time of flight mass spectrometry. J. Clin. Microbiol. 47(7):2284-2287. http:// dx.doi.org/10.1128/JCM.00175-09. PMid:19403759.

Lee S.H., Camargo C.H., Goncalves J.L., Cruz A.G., Sartori B.T., Machado M.B. \& Oliveira C.A. 2012. Characterization of Staphylococcus aureus isolates in milk and the milking environment from small-scale dairy farms of Sao Paulo, Brazil, using pulsed-field gel electrophoresis. J. Dairy Sci. 95(12):7377-7383. http://dx.doi.org/10.3168/jds.2012-5733. PMid:23040016.

Leigh J.A. 1999. Streptococcus uberis: a permanent barrier to the control of bovine mastitis? Vet. J. 157(3):225-238. http://dx.doi.org/10.1053/ tvjl.1998.0298. PMid:10328836.

Murray P.R., Baron E.J., Jorgensen J.J., Pfaller M.A. \& Yolken R.H. 2003. Manual of Clinical Microbiology. 8th ed. ASM Press, Washington, D.C. 2113p.

Oliver S.P.O., González R.N., Hogan J.S., Jayarao B.M. \& Owens W.E. 2004 Microbiological procedures for the diagnosis of bovine udder infection and determination of milk quality. National Mastitis Council Inc., Verona, WI, USA. $47 \mathrm{p}$.
Olson P.E., Qi B., Que Junior L. \& Wackett L.P. 1992. Immunological demonstration of a unique 3,4-dihydroxyphenylacetate 2,3-dioxygenase in soil Arthrobacter strains. Appl. Environ. Microbiol. 58(9):2820-2826. PMid:1444392.

Reis C.B., Barreiro J.R., Moreno J.F., Porcionato M.A. \& Santos M.V. 2011. Evaluation of somatic cell count thresholds to detect subclinical mastitis in Gyr cows. J. Dairy Sci. 94(9):4406-4412. http://dx.doi.org/10.3168/ jds.2010-3776. PMid:21854914.

Ryzhov V.\& Fenselau C. 2001. Characterization of the protein subset desorbed by MALDI from whole bacterial cells. Anal. Chem. 73(4):746-750. http:// dx.doi.org/10.1021/ac0008791. PMid:11248887.

Santos E.M.P., Brito M.A.V.P., Lange C., Brito J.R.F. \& Cerqueira M.M.O.P. 2007. Streptococcus and related genera as etiological agents of bovine mastitis. Acta Scient. Vet. 35:17-27.

Schukken Y.H., Gonzalez R.N., Tikofsky L.L., Schulte H.F., Santisteban C.G., Welcome F.L., Bennett G.J., Zurakowski M.J. \& Zadoks R.N. 2009. CNS mastitis: nothing to worry about? Vet. Microbiol. 134(1/2):9-14. http:// dx.doi.org/10.1016/j.vetmic.2008.09.014. PMid:18842362.

Sogawa K., Watanabe M., Sato K., Segawa S., Ishii C., Miyabe A., Murata S., Saito T. \& Nomura F. 2011. Use of the MALDI BioTyper system with MALDITOF mass spectrometry for rapid identification of microorganisms. Anal. Bioanal. Chem. 400(7):1905-1911. http://dx.doi.org/10.1007/s00216011-4877-7. PMid:21442367.

Steensels D., Verhaegen J. \& Lagrou K. 2011. Matrix-assisted laser desorption ionization-time of flight mass spectrometry for the identification of bacteria and yeasts in a clinical microbiological laboratory: a review. Acta Clin. Belg. 66(4):267-273. PMid:21938981

Suarez S., Ferroni A., Lotz A., Jolley K.A., Guérin P., Leto J., Dauphin B., Jamet A., Maiden M.C., Nassif X. \& Armengaud J. 2013. Ribosomal proteins as biomarkers for bacterial identification by mass spectrometry in the clinical microbiology laboratory. J. Microbiol. Methods 94(3):390-396. http:// dx.doi.org/10.1016/j.mimet.2013.07.021. PMid:23916798.

Thorberg B.M., Kuhn I., Aarestrup F.M., Brandstrom B., Jonsson P. \& DanielssonTham M.L. 2006. Pheno- and genotyping of Staphylococcus epidermidis isolated from bovine milk and human skin. Vet. Microbiol. 115(1-3):163172. http://dx.doi.org/10.1016/j.vetmic.2006.01.013. PMid:16530988.

Tomazi T., Gonçalves J.L., Barreiro J.R., Braga P.A.C., Silva L.F.P., Eberlin M.N. \& Santos M.V. 2014. Identification of coagulase-negative staphylococci from bovine intramammary infection by matrix-assisted laser desorption ionization-time of flight mass spectrometry. J. Clin. Microbiol. 52(5):16581663. http://dx.doi.org/10.1128/JCM.03032-13. PMid:24622096.

Welker M. 2011. Proteomics for routine identification of microorganisms. Proteomics 11(15):3143-3153. http://dx.doi.org/10.1002/pmic.201100049. PMid:21726051.

Werner B., Moroni P., Gioia G.A., Lavín-Alconero L., Yousaf A., Charter M., Carter B., Bennett J.A., Nydam D.V., Welcome F.L. \& Schukken Y.H. 2014. Short communication: genotypic and phenotypic identification of environmental streptococci and association of Lactococcus lactis ssp. lactis with intramammary infections among different dairy farms. J. Dairy Sci. 97(11):6964-6969. http://dx.doi.org/10.3168/jds.2014-8314. PMid:25242419. 